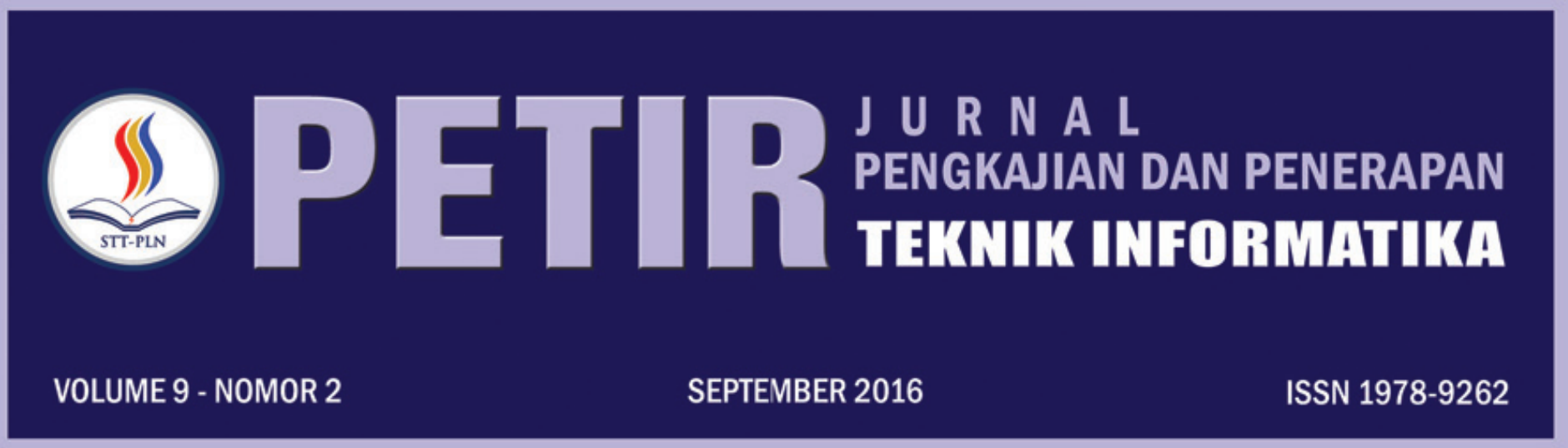

ANALISA SPASIAL UNTUK MELIHAT TINGKAT KESEJAHTERAAN MASYARAKAT DI PROVINSI BANTEN Muhamad Jafar Elly; Reza Pahlevi

PENENTUAN WILAYAH RAWAN PENYAKIT BERBASIS LINGKUNGAN DI JAKARTA TIMUR MENGGUNAKAN SISTEM INFORMASI GEOGRAFIS

Atiqah Meutia Hilda; Muhamad Jafar Elly; Windu Nugroho Cahyo Pamungkas

APLIKASI PENCARIAN USTADZ UNTUK WILAYAH DKI JAKARTA MENGGUNAKAN ALGORITMA HAVERSINE FORMULA BERBASIS ANDROID

Harni Kusniyati; Haries Fadhillah

PERENCANAAN ARSITEKTUR ENTERPRISE PERGURUAN TINGGI DENGAN PENDEKATAAN ENTERPRISE ARCHITECTURE PLANNING (EAP) (STUDI KASUS POLITEKNIK PIKSI GANESHA)

M. Farid Rifai

PERANCANGAN E-KATALOG PADA PERPUSTAKAAN DIGITAL STT-PLN BERBASIS WEB

Yessy Fitriani; Yasni Djamain; Risalatulina Dwi Kurniati

APLIKASI SISTEM GPS KEGIATAN OPERASIONAL PERSAMPAHAN DINAS PENGELOLAAN SAMPAH, PERTAMANAN DAN PEMAKAMAN (DP4) KOTA SUKABUMI

Yasmi Afrizal; Julian Chandra W
PERANCANGAN APLIKASI PENGOLAHAN DATA KAS BERBASIS ONLINE
(STUDI KASUS : KEMENTRIAN ' $X$ ')
Dian Hartanti; Lingga Desyanita

PERANCANGAN SISTEM INFORMASI PESERTA SERTIFIKASI

(Studi kasus LSP Piksi Ganesha)

Hendra Jatnika

RANCANG BANGUN APLIKASI SEC-WAY GUNA PENGINGAT BEPERGIAN DILENGKAPI INFO CUACA DAN CCTV JALAN RAYA LOKASI PILIHAN BERBASIS ANDROID STUDI KASUS DKI JAKARTA

Yasni Djamain; Intan Ratna Sari Yanti; Hari Wibowo

PREDIKSI PENERIMAAN SISWA BARU PADA MADRASAH ALIYAH AS-SAYAFI'IYAH 02 MENGGUNAKAN METODE TIME SERIES

Sarwo; Hermawan

PERANCANGAN SIMULASI MEDIA PEMBELAJARAN DENGAN METODE DIVISION REMAINDER UNTUK PENCARIAN ALAMAT RELATIF PADA PROSES PENEMPATAN DATA

Dewi Arianti Wulandari; Darma Rusjdi

ANALISIS SISTEM PENENTUAN LOKASI GANGGUAN JARINGAN DISTRIBUSI LISTRIK TERINTEGRASI GOOGLE MAP Abdul Haris; Herman Bedi Agtriadi

\begin{tabular}{|c|c|c|c|c|c|c|}
\hline \multirow{2}{*}{ 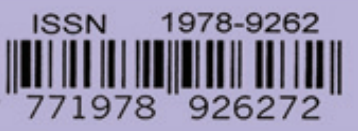 } & \multicolumn{6}{|c|}{ SEKOLAH TINGGI TEKNIK - PLN (STT-PLN) } \\
\hline & PETIR & VOL. 9 & NO. 2 & HAL. 89 - 166 & JAKARTA, SEPTEMBER 2016 & ISSN 1978-9262 \\
\hline
\end{tabular}




\title{
PREDIKSI PENERIMAAN SISWA BARU PADA MADRASAH ALIYAH AS- SAYAFI'IYAH 02 MENGGUNAKAN METODE TIME SERIES
}

\author{
Sarwo ${ }^{1)}$ \\ Hermawan ${ }^{2}$ \\ 1) Sekolah Tinggi Manajemen Informatika dan Komputer Mercusuar \\ Jl. Raya Jatiwaringin 144, Pondok Gede Bekasi 17411 Indonesia \\ email : sarwo@mercusuar.ac.id \\ 2) Sekolah Tinggi Manajemen Informatika dan Komputer Mercusuar \\ JI. Raya Jatiwaringin 144, Pondok Gede Bekasi 17411 Indonesia \\ email : hermawanawang@gmail.com
}

\begin{abstract}
Penerimaan siswa tahun ajaran baru dapat mengalami peningkatan dan dapat juga mengalami penurunan. Hal tersebut merupakan suatu masalah yang dihadapi Madrasah Aliyah As-Syafi'iyah 02 dalam menentukan langkah-langkah strategi kedepannya sehingga diperlukan adanya prediksi atau peramalan untuk mengetahui perolehan jumlah siswa baru, agar semua kebijakan dan keputusan dalam menyusun perencanaan kedepan dapat terpenuhi dengan baik.

Dalam penelitian ini dilakukan untuk mengindentifikasi dan memprediksi jumlah siswa baru, yaitu dengan satu teknik dalam Data Mining yang digunakan peneliti ini adalah teknik Time Series untuk memprediksi perolehan jumlah siswa baru pada tahun 2016/2017 di Madrasah Aliyah As-Syafi'iyah 02, dimana hasil prediksi tersebut dapat memberikan kemudahan kepada pihak Madrasah Aliyah As-Syafi'iyah 02 dalam menentukan langkah-langkah strategi dalam mengambil keputusan dan kebijakan pada tahun yang akan datang.

Berdasarkan hasil penelitian yang telah dilakukan untuk prediksi jumlah penerimaan siswa baru. Salah satunya adalah teknik Time Series dimana teknik ini dapat mengetahui target penerimaan siswa baru yang mengalami tingkat akurasi prediksi error yang terbaik adalah menggunakan alpha 0,9 dengan hasil perhitungan MAPE yaitu mencapai 23,582, MAD yaitu mencapai 13,006 dan MSD yaitu mencapai 217,667 dengan tingkat akurasi diterima mencapai 95\% sedangkan untuk tingkat tidak diterima mencapai 5\%, maka hasil penerimaan siswa baru di tahun ajaran 2016/2017 adalah 79 siswa. Sehingga dapat membantu memberikan informasi berharga kepada Madrasah Aliyah As-Syafi'iyah 02 sebagai gambaran dasar pengambilan keputusan.
\end{abstract}

Key words : Prediksi, Penerimaan Siswa, Metode Time Series, Data Mining, Minitab versi 16.

\section{Pendahuluan}

Sekolah atau lembaga pendidikan formal setiap tahun rutin mengadakan kegiatan penerimaan siswa baru. Jumlah siswa baru pada penerimaan siswa tahun ajaran baru dapat mengalami peningkatan dan dapat juga mengalami penurunan, sehingga diperlukan adanya prediksi atau peramalan untuk mengetahui perolehan jumlah siswa baru, agar semua kebijakan dan keputusan dalam menyusun perencanaan manajemen ke depan dapat terpenuhi dengan baik di Madrasah Aliyah As-Syafi'iyah 02 yang telah berupaya melakukan prediksi jumlah siswa baru berdasarkan pengalaman tahun sebelumnya namun hasilnya tidak tepat. Turun naik jumlah siswa baru tersebut merupakan suatu masalah yang dihadapi Madrasah Aliyah As-Syafi'iyah 02 dalam menentukan langkah-langkah strategis dan kebijakan terkait dengan promosi sekolah, penyediaan fasilitas/inprastruktur sekolah dan target penerimaan siswa baru tahun-tahun selanjutnya.

Beberapa solusi prediksi penerimaan siswa baru yang dapat diselesaikan dengan data mining adalah menebak target jumlah siswa baru, melihat pola dari waktu ke waktu. (Richard, 2011).
Berdasarkan permasalahan di atas dibuatlah prediksi penerimaan siswa baru menggunakan metode Time Series pada Madrasah Aliyah AsSyafi'iyah 02 sehingga dari penelitian ini dapat diketahui jumlah siswa baru yang baik dalam kurun waktu tertentu.

Berdasarkan yang telah diuraikan diatas, maka rumusan masalah pada penelitian ini adalah "Bagaimana penerapan metode time series dapat memprediksi jumlah siswa baru di tahun yang akan datang" dan "Dari hasil prediksi dapat membantu dalam pengambilan keputusan yang baik"

\section{Landasan Teori}

\subsection{Pengertian Prediksi}

Prediksi atau peramalan (Forecasting) adalah kegiatan memperkirakan atau memprediksi apa yang akan terjadi pada masa yang akan datang dengan waktu yang relitif lama. Sedangkan ramalan adalah suatu situasi atau kondisi yang akan diperkirakan kan terjadi pada masa yang akan datang (William \& Choung, 2014, p. 76)

Menurut Hary Prasetya dan Fitri Lukiastuti (Hary \& Fitri, 2013, p. 43), peramalan atau prediksi adalah "seni dan ilmu untuk meperkirakan kejadian 
dimasa depan melalui pengujian di masa lalu". Pengujian tersebut atas dasar pola-pola di waktu yang lalu dengan melibatkan pengambilan data masa lalu dan menempatkannya ke masa yang akan datang dengan model matematis. Prediksi atau peramalan adalah proses memperkirakan berapa kebutuhan dimasa datang yang meliputi kebutuhan kuantitas, kualitas, waktu dan lokasi yang dibutuhkan dalam rangka memenuhi permintaan barang atau jasa (Hakim \& Prasetyawan, 2013, p. 29).

Peramalan adalah upaya mempekirakan apa yang terjadi di masa depan, berbasis pada metode ilmiah (ilmu dan teknologi) serta dilakukan secara sistematis (Sri Mulyono, 2010, p. 10).

\subsection{Pengertian Time Series}

Perencanaan dan pembuatan keputusan membutuhkan dugaan-dugaan tentang apa yang akan terjadi dimasa yang akan datang. Karena itu analisis diharapkan untuk membuat ramalanramalan, salah satunya adalah dengan model time series.

Time series adalah serangakain nilai-nilai variabel yang disusun berdasarkan waktu (Sri Mulyono, 2010, p. 10). Analisis time series mempelajari pola gerakan-gerakan nilai-nilai variabel pada satu interval waktu (misal minggu, bulan, dan tahun) yang teratur.

(Soezati, Zanzawi. 2010) mengemukakan bahwa pendugaan masa depan dilakukan berdasarkan nilai masa lalu. Tujuan metode peramalan deret berkala (time series) seperti ini adalah menemukan pola dalam deret historis dan mengekstrapolasikan pola tersebut kemasa depan.

Langkah penting dalam memilih suatu deret berkala (time series) yang tepat adalah dengan mempertimbangkan jenis pola data, sehingga metode yang paling tepat dengan pola tersebut dapat diuji. Pola data menurut Spyros (Soezati, Zanzawi. 2010) dapat dibedakan menjadi empat jenis siklis dan trend.

Pola Harizontal (H)

Terjadi apabila nilai data fluktuasi disekitar nilai rata-rata yang konstan. Suatu calon mahasiswa baru yang tidak meningkat dan menurun selama waktu tertentu, termasuk kedalam pola ini.

\section{Pola Musiman}

Terjadi apabila suatu deret dipengaruhi oleh musiman (misal kuartal tahun tertentu)

\section{Pola Siklis}

Terjadi apabila datanya dipengaruhi oleh fluktuasi ekonomi jangka panjang seperti yang behubungan siklis bisnis.

\section{Pola Trend}

Terjadi apabila terdapat kenaikan atau penurunan sekuler jangka panjang dalam data.

\subsection{Prediksi dengan metode Penghalusan Eksponensial (exponential smoothing)}

Exponential smoothing adalah suatu tipe teknik peramalan rata-rata bergerak yang melakukan penimbangan terhadap data masa lalu dengan cara eksponensial sehingga data paling akhir mempunyai bobot atau timbangan lebih besar dalam rata-rata bergerak. (Sriyati, 2010, P, 279).

1. Metode penghalusan eksponensial orde satu (single exponential smoothing)

Metode penghalusan eksponensial orde satu (single exponential smoothing) sebenarnya merupakan perkembangan dari metode rata-rata bergerak (moving average) sederhana. Metode ini dipergunakan secara luas di dalam Peramalan (forecasting) karena sederhana, efisien di dalam perhitungan dan perubahan ramalan, mudah disesuaikan dengan perubahan data, dan ketelitian metode ini cukup besar.

Rumus :

$$
S_{t+1}=a x_{T}+(1-a) S_{t}
$$

Keterangan :

$S_{t+1}=$ Nilai prediksi untuk periode waktu ke-t

$X_{t}=$ Nilai actual untuk periode waktu yang lalu ke-t

$S_{t}=$ Nilai prediksi untuk satu periode waktu lalu ke-t

$a=$ Konstanta nilai pemulusan

2. Metode penghalusan eksponensial orde dua (double exponential smoothing)

Metode double exponential smoothing yang dapat digunakan untuk menyelesaikan trend linier adalah metode dua paramenter dari Holt. Metode Holt nilai trend tidak dimuluskan dengan pemulusan ganda secara langsung, tetapi proses pemulusan trend dilakukan dengan menggunaka paramenter yang berbeda dengan paramenter yang digunakan pada pemulusan data asli. Metode double exponential smoothing digunakan ketika data menunjukan adanya trend. Rumus double exponential smoothing:

Rumus :

$$
S t=a x_{t}+(1-a)\left(S_{t-1}+T_{t-1}\right.
$$

\section{Keterangan :}

$S t \quad=$ Nilai pemulusan tunggal

$X_{t} \quad=$ Nilai sebenarnya pada waktu ke-t

$\mathrm{Tt}=$ Pemulusan trend

$F(t+m)=$ Nilai Prediksi

$m=$ Periode masa mendatang

$a, \beta=$ Konstanta dengan nilai antara 0 dan 1

\subsection{Penghitungan Manual Pengukuran Akuras} hasil Prediksi dengan Pemulusan Eksponensial Orde Satu/Tunggal (Single Eksponential Smoothing)

Dalam penelitian ini, untuk mengukur akurasi hasil prediksi penulis menggunakan pengukuran Mean Deviation Absolute (MAD), Mean Squared Error (MSE) dan Mean Absolute Percentage Error (MAPE). 
a. Mean Deviation Absolute (MAD)

MAD merupakan salah satu cara yang dapat digunakan untuk dapat mengetahui ukuran kesalahan peramalan. MAD merupakan rata-rata dari nilai absolute simpangan. Rumus perhitungan MAD adalah:

$$
\mathrm{MAD}=\underline{\sum_{t=1}^{n}\left|X_{t}-S_{t}\right|}
$$

\section{$\mathrm{n}$}

Ket

$\mathrm{X}_{\mathrm{t}} \quad=$ Nilai data aktual pada periode $\mathrm{t}$

$\mathrm{S}_{\mathrm{t}} \quad=$ Nilai hasil peramalan pada periode $\mathrm{t}$

$\mathrm{t}=$ Periode peramalan

$\mathrm{n} \quad=$ Banyaknya data

Sebelum menghitung rata-rata nilai absolute kita hitung dulu selisih error dimana nilai aktual dikurangi nilai prediksi/ramalan (data aktual - nilai prediksi).

b. Mean Squared Error (MSE)

MSE merupakan salah satu cara yang dapat digunakan untuk dapat mengetahui ukuran kesalahan peramalan. Memiliki arti rata-rata kesalahan peramalan yang dikuadratkan. Rumus perhitungan MSE adalah:

$$
\text { MSE : } \sum_{t=1}^{n}(X t-S t)^{2}
$$

Keterangan

$\mathrm{X}_{\mathrm{t}} \quad=$ Nilai data aktual pada periode $\mathrm{t}$

$\mathrm{S}_{\mathrm{t}} \quad=$ Nilai hasil peramalan pada periode $\mathrm{t}$

$=$ Periode peramalan

= Banyaknya data

Sama seperti penghitungan Mean Absolute Deviation (MAD), sebelum menghitung Mean Squared Error (MSE) kita hitung dulu jumlah selisih antara data aktual dengan data peramalan.

c. Mean Absolute Percentage Error (MAPE)

Mean Absolute Percentage Error (MAPE) dihitung dengan menggunakan kesalahan absolut pada tiap periode dibagi dengan nilai observasi yang nyata untuk periode itu. Kemudian, meratarata kesalahan persentase absolut tersebut. MAPE merupakan pengukuran kesalahan yang menghitung ukuran presentase penyimpangan antara data aktual dengan data peramalan. Nilai MAPE dapat dihitung dengan persamaan berikut.

$$
\mathrm{MAPE}=100 \% \sum_{t=1}^{n}|\mathrm{Xt}-\mathrm{St}| \backslash \mathrm{Xt}
$$

\section{n}

Keterangan:

$\mathrm{X}_{\mathrm{t}} \quad=$ Nilai data actual pada periode $\mathrm{t}$

$\mathrm{S}_{\mathrm{t}} \quad=$ Nilai hasil peramalan pada periode $\mathrm{t}$

$\mathrm{t}=$ Periode peramalan

$\mathrm{n} \quad=$ Banyaknya data

Untuk menentukan Mean Absolute Percentage Error (MAPE) kita bisa mengambil data perhitungan dari Mean Absolute Deviation (MAD) yang kemudian ditindaklanjuti dengan perhitungan menggunakan rumus MAPE.

\subsection{Program Minitab 16}

Perkembangan ilmu pengetahuan dan teknologi sekarang ini telah menciptakan perangkat yang memudahkan dan mempersingkat kerja manusia dalam berbagai hal seperti pengolahan data statistik.Minitab merupaka salah satu perangkat lunak yang dibuat untuk mempermudah proses peramalan jika data yang digunakan sangat banyak. Penggunaan software minitab dalam kegiatan ini bertujuan agar proses peramalan mudah dilakukan dan hasil peramalan yang diperoleh juga lebih akurat. Minitab merupakan perangkat lunak yang digunakan sebagai media pengolahan data yang dapat menyediakan berbagai jenis perintah yang menyediakan perintah dalam proses pemasukan data, manipulasi data, pembuatan grafik, penganalisaan numerik, dan analisis statistik (irwan, Nur. 2000). Adapun langkahlangkah penggunaan software minitab dalam melakukan peramlan adalah sebagai berikut. Minitab

Pemasukan / Input Data ke Dalam Program

Langkahnya yaitu jalankan software minitab dengan cara klik Start $\rightarrow$ Minitab 11 for window $\rightarrow$ Minitab, maka akan muncul tampilan seperti di bawah ini:

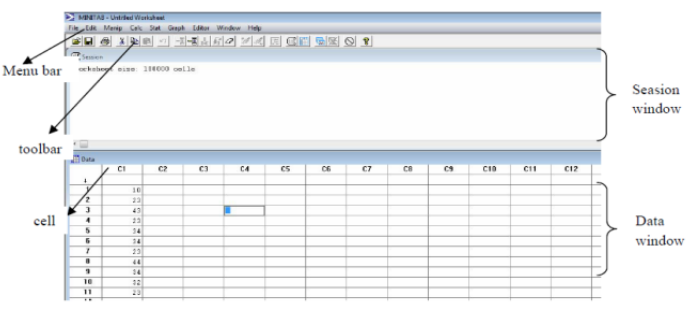

Gambar 1 Tampilan Worksheet Minitab

Untuk memasukan data runtun waktu yang akan kita olah terlebih dahulu klik pada cell baris 1 kolom C1. Kemudian ketik data pertama dan seterusnya secara menurun dalam kolom yang sama. Dengan format kolom tersebut harus angka/ numerik.

\section{Menggambar Grafik Data Runtun Waktu}

Langkah-langkahnya adalah:

1) Pilih menu Stat, caranya dengan klik tombol kiri pada mouse pilih menu Time Series $\rightarrow$ Singel Exponential Smooting.

2) Kemudian klik data yang akan digambar grafiknya misal kolom $\mathrm{C} 1$, kemudian klik Select, maka kolom $\mathrm{Y}$ baris pertama akan muncul tulisan $\mathrm{C} 1$. Kalau data yang ingin digambar grafiknya lebih dari satu. Letakan kursor pada $Y$ baris 2 dan seterusnya. Kemudian pilih kolom data yang akan digambarkan grafiknya. Maka akan muncul tampilan seperti di bawah ini: 


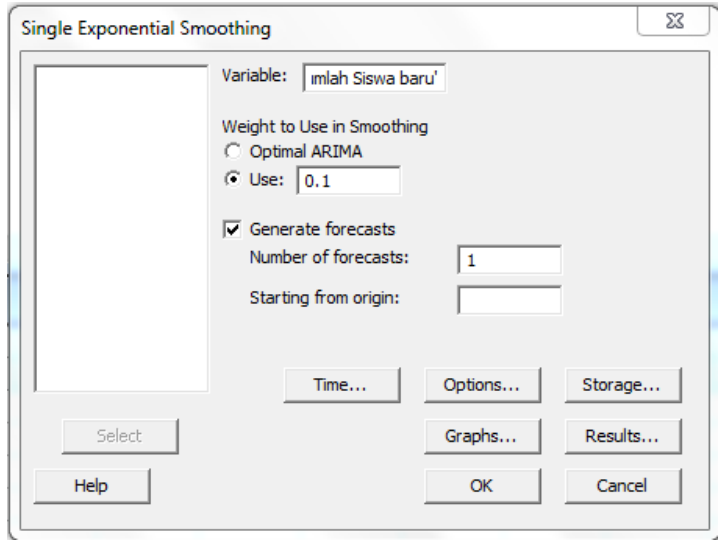

Gambar 2. Pemilihan Menu Singel Exponential Smooting

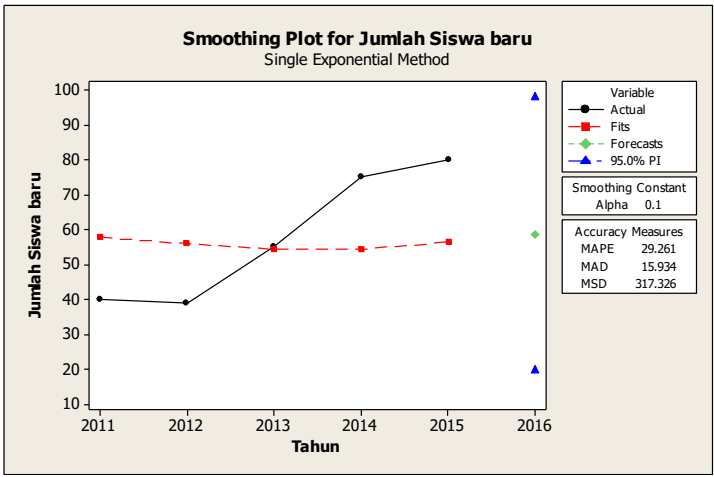

Gambar 3. Grafik Menggunakan alpha 0.1 Singel Exponential Smooting

\section{Hasil Pembahasan}

\subsection{Penelitian Terkait}

Penulis mengutip dari jurnal (Fernando \& Setiono, 2012) dengan judul " Perancangan Data Warehouse Dan Penerapan Algoritma Time Series Untuk Memprediksi Informasi Pertumbuhan Penduduk Di Provinsi Bengkulu" membahas tentang penerapan algoritma time series untuk memprediksikan pertumbuhan penduduk di provinsi bengkulu yang selalu meningkat hal ini menciptakan kondisi data yang berlimpah tapi minim informasi.

Pada penulisan yang dilakukan oleh (Kristien \& Sofia, 2015) dengan judul "Analisa Dan Penerapan metode Single Exponential Smoothing Untuk Prediksi Penjualan Pada Periode Tertentu (studi kasus : PT. Media cemara kreasi)" membahas tentang prediksi barang apa yang harus dijual ditiap bulannya.

Pada penulisan yang dilakukan oleh (Dimas, 2011) dengan judul "Analisis Runtun Waktu Untuk Meramalkan Jumlah Pasien Yang Berobat Di Puskesmas Blora Dengan Menggunakan Software Minitab 14" membahas tentang untuk mengetahui model analisis runtun waktu yang tepat untuk peramalan jumlah pasien yang berobat di Puskesmas Blora dan selanjutnya diketahui besar peramalan jumlah pasien yang berobat di Puskesmas wilayah Blora pada periode yang telah ditentukan ke depannya.
Pada penulisan yang dilakukan (Haryadi, 2012) dengan judul "Prediksi Jumlah Penerimaan Siswa SMK Swasta Tahun Ajaran 2011/2012" membahas tentang prediksi jumlah siswa Sekolah Menengah Kejuruan (SMK) swasta modern di sebuah propinsi di Kalimantan dengan pendekatan enam metode forecasting yaitu Linear Regression, Exponential Smoothing With Trend, Exponential Smoothing, Weighted Moving Average, Moving Average, dan Naïve Method, selain menggunakan perhitungan secara Manual juga menggunakan pendekatan QM for windows, sebagai perbandingan.

Pada penulisan yang dilakukan oleh (Sidik, 2012) dengan judul "Forecasting Volume Produksi Tanaman Pangan, Tanaman Perkebunan Rakyat Kab. Magelang Dengan Metode Exponential Smoothing Berbantu Minitab" membahas tentang bagaimana penggunaan Metode Exponential Smoothing untuk peramalan volume produksi tanaman pangan, produksi perkebunan rakyat Kabupaten Magelang dengan Minitab

\subsection{Sumber Data}

Pada proses ini data yang digunakan yaitu dari tahun 2011 sampai dengan tahun 2015 pada Madrasah Aliyah As-Syafi'iyah 02 adalah sebagai berikut :

Tabel 1 Data Siswa Baru dari Tahun 2011-2015

\begin{tabular}{|l|l|}
\hline Tahun & Jumlah Siswa Baru \\
\hline 2011 & 40 \\
\hline 2012 & 39 \\
\hline 2013 & 55 \\
\hline 2014 & 75 \\
\hline 2015 & 80 \\
\hline
\end{tabular}

\subsection{Hasil Penerapan Time Series}

Menggunakan Aplikasi Minitab 16

Dari hasil penerapan menggunakan algoritma time series untuk memprediksi penerimaan siswa baru menggunakan data siswa baru yang di dapat dariMadrasah Aliyah As-Syafi'iyah 02 dengan menggunakan Minitab 16 adalah sebagai berikut.

1. Langkah Pertama yaitu penginputan data siswa baru ditunjukan gambar dibawah ini.

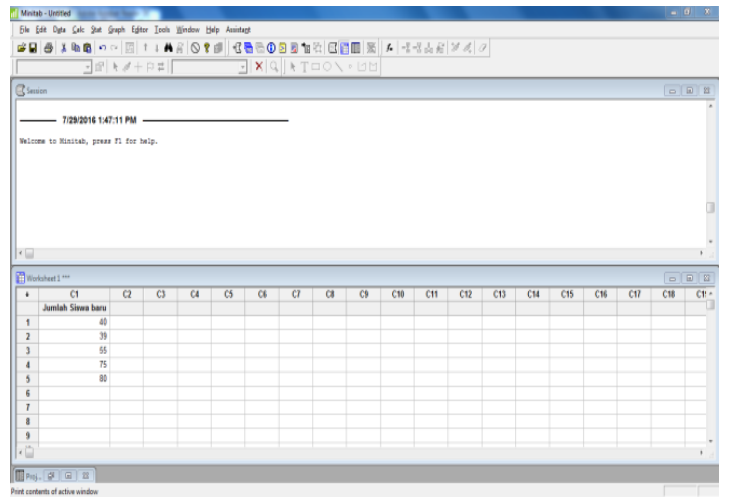

Gambar 4. Tampilan Input Data Jumlah Siswa 
2. Langkah kedua yaitu pemilihan stat untuk memasukan data siswa baru kedalam sistem algoritma time series yang menggunakan model singel exponesial smooting dari nilai alpha $0,1,0,5$ dan 0,9 , seperti yang ditunjukan pada gambar dibawah ini.

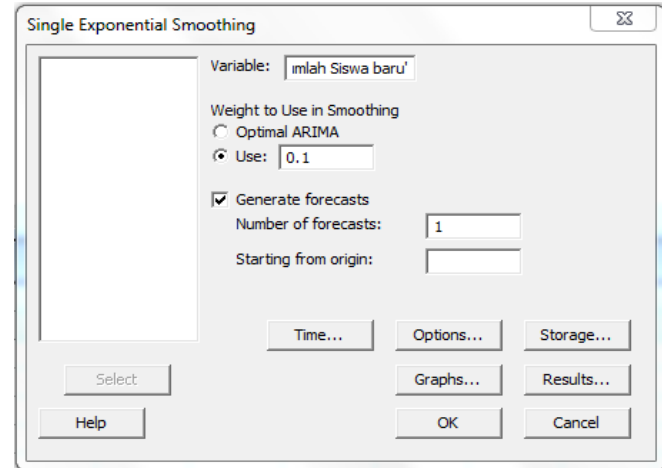

Gambar 5. Tampilan Algoritma Time Series dengan Model Singel Exponensial Smooting

3. Yang ketiga yaitu menunjukan grafik hasil pengujian dari perhitungan prediksi menggunakan aplikasi minitab 16 dengan algoritma time series yang diperoleh dari model singel exponensial smooting dari nilai alpha $0,1,0,5$ dan 0,9 , seperti yang ditunjukan pada gambar dibawah ini.

a. Grafik nilai alpha 0,1

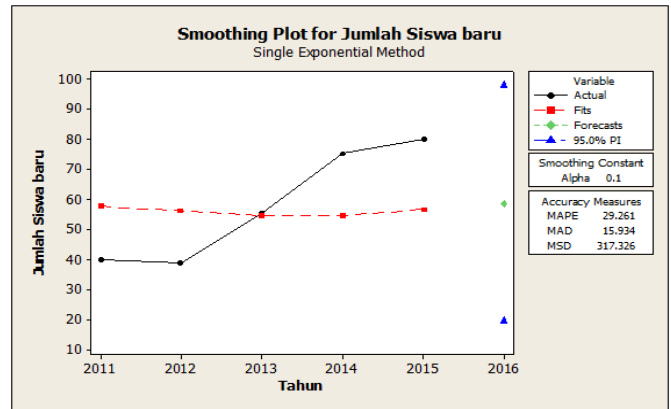

Gambar 6. Tampilan Grafik Prediksi Jumlah Siswa Baru Dengan Alpha 0,1

Dari hasil gambar grafik diatas maka tingkat akurasi prediksi error untuk nilai alpha 0,1, seperti yang ditunjukan pada gambar 7 .

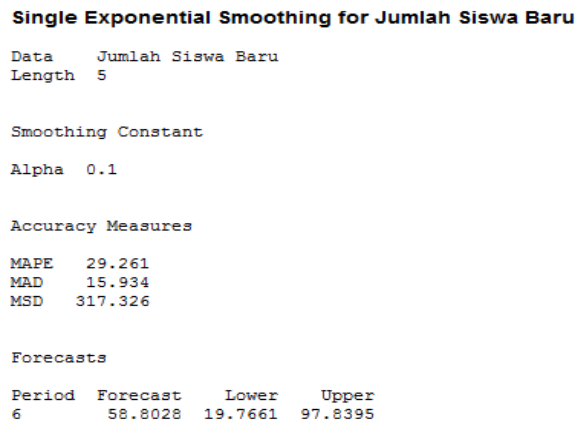

Gambar 7. Tampilan Tingkatan Akurasi error dan Prediksi Jumlah Siswa Baru dengan Alpha 0,1
Dengan demikian hasil prediksi menggunakan algoritma time series dari perhitungan model single exponensial smoting yang menggunakan nilai alpha 0,1 yaitu denggan tingkat akurasi error untuk MAPE 29,261, MAD 15,934 dan MSD 317,326 maka prediksi jumlah siswa baru di tahun 2016 untuk perhitungan menggunakan alpha 0,1 adalah 58,8028 yang dibulatkan menjadi 59 siswa.

b. Grafik nilai alpha 0,5

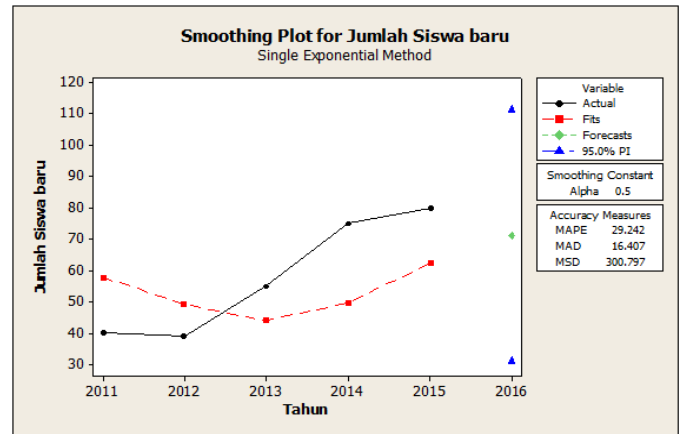

Gambar 8. Tampilan Grafik Prediksi Jumlah Siswa Baru Dengan Alpha 0,5

Dari hasil gambar grafik diatas maka tingkat akurasi prediksi error untuk nilai alpha 0,5, seperti yang ditunjukan pada gambar 9 .

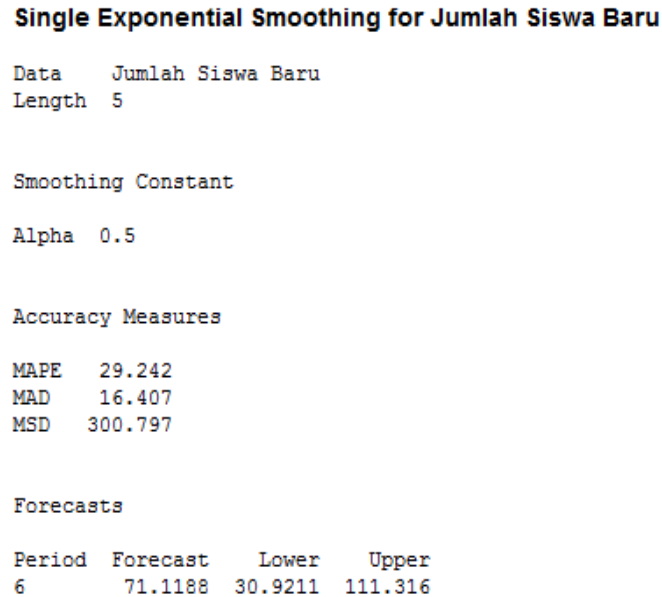

Gambar 9. Tampilan Tingkatan Akurasi error dan Prediksi Jumlah Siswa Baru Dengan Alpha 0,5

Dengan demikian hasil prediksi menggunakan algoritma time series dari perhitungan model single exponensial smoting yang menggunakan nilai alpha 0,5 yaitu dengan tingkat akurasi error untuk MAPE 29,243, MAD 16,407 dan MSD 300,797 maka prediksi jumlah siswa baru di tahun 2016 untuk perhitungan menggunakan alpha 0,1 adalah 71,1188 yang dibulatkan menjadi 71 siswa.

c. Grafik nilai alpha 0,9 


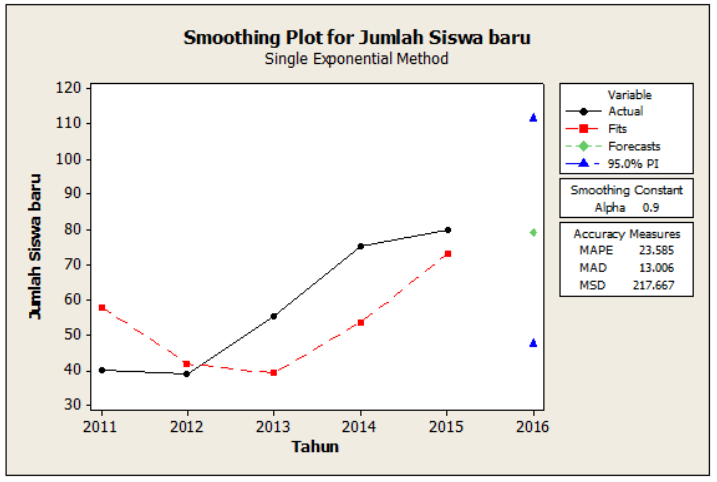

Gambar 10. Tampilan Grafik Prediksi Jumlah Siswa Baru Dengan Alpha 0,9

Dari hasil gambar grafik diatas maka tingkat akurasi prediksi error untuk nilai alpha 0,9, seperti yang ditunjukan gambar dibawah ini.

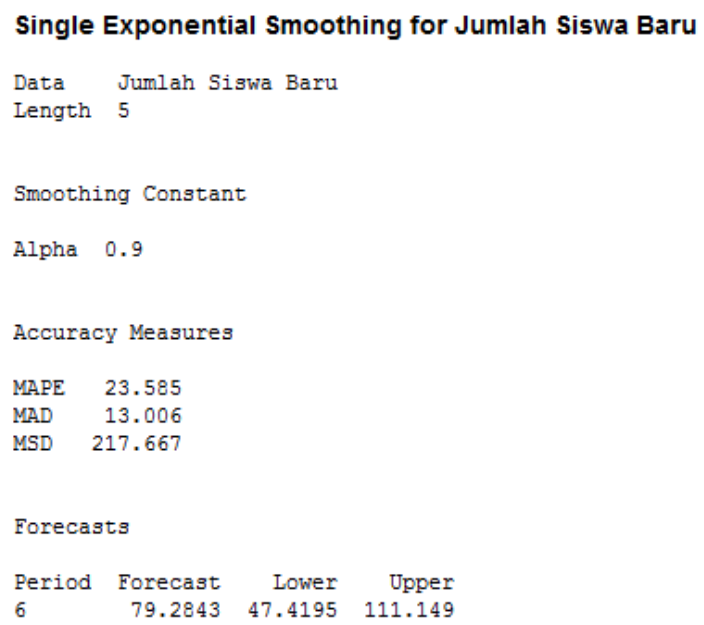

Gambar 11. Tampilan Tingkatan Akurasi Kerrorran dan Prediksi Jumlah Siswa Baru Dengan Alpha 0,9

Dengan demikian hasil prediksi menggunakan algoritma time series dari perhitungan model single exponensial smoting yang menggunakan nilai alpa 0,9 yaitu dengan tingkat akurasi error untuk MAPE 23,585, MAD 13,006 dan MSD 217,667 maka prediksi jumlah siswa baru di tahun 2016 untuk perhitungan menggunakan alpha 0,9 adalah 79,2843 yang dibulatkan menjadi 79 siswa.

\section{Kesimpulan}

Hasil penelitian ini menyimpulkan bahwa data time series dapat diprediksi dengan menggunakan model singel exponensial smooting, dengan hasil perbandingan tingkatan akurasi prediksi ke errorran terkecil dari nilai alpha $0,1,0,5$ dan 0,9 yaitu terdapat ditingkatan nilai alpha 0,9 dengan akurasi kerrorran terkecil sebesar MAPE 23,585, MAD 13,006 dan MSD 217,667. Sehinggga menghasilkan prediksi penerimaan siswa baru di tahun 2016 sebesar 79 siswa dengan tingkat keberhasilannya yang diterima mencapai 95\% dan tingkat kegagalanya yang tidak diterima mencapai $5 \%$, maka disimpulkan bahwa nilai alpha 0,9 lebih dominan untuk tingkat keberhasilannya, Jika dibandingkan dengan nilai alpha 0,1 dan 0,5 yang tingkatan akurasi error sangat tinggi.

\section{REFERENSI}

Dimas. (2011). Analisis Runtun Waktu Untuk Meramalkan Jumlah Pasien Yang Berobat Di Puskesmas Blora Dengan Menggunakan Software Minitab 14. Universitas Negeri Semarang.

Haryadi. (2012). Prediksi Jumlah Penerimaan Siswa SMK Swasta Tahun Ajaran 2011/2012. Jakarta Barat.

Hary Prasetya, F. L. (2013). Manajemen Operasi. Jakarta: PT. Buku Kita.

H. N., \& Prasetyawan. (2013). Perencanaan dan Pengendalian Produksi. Yogyakarta: Graha Ilmu.Castleman, Kenneth R., 1998, "Digital Image Processing", Prentice Hall, New Jersey.

Irwan, Nur. 2000. Mengolah Data Statistik Dengan Mudah Menggunakan Minitab 14. Yogyakarta: Andi Ofset.

Kristien \& Sofian. (2015). Analisa Dan Penerapan metode Single Exponential Smoothing Untuk Prediksi Penjualan Pada Periode Tertentu (studi kasus : PT. Media cemara kreasi). Jakarta

Nur Sidik. (2012). Forecasting Volume Produksi Tanaman Pangan, Tanaman Perkebunan Rakyat Kab. Magelang Dengan Metode Exponential Smoothing Berbantu Minitab. Universitas Negeri Semarang

Richard. (2011). Perception-Based Approach To Time Series Data Mining.

Roby , S. A. (2012). Perancangan Data Warehouse Dan Penerapan Algoritma Time Series Untuk Memprediksi Informasi Pertumbuhan Penduduk Di Provinsi Bengkulu. Palembang.

Sri Mulyono. (2010). Analisis Times Series. Jakarta: Elex Media Komputindo.

Soejati, Zanzawi. 2010. Analisis Runtun Waktu. Jakarta: Karunia Jakarta.

Sriyati. 2005. Forecasting Jumlah Pelanggan Koran Sore Wawasan Tahun 2005 Berdasarkan Hasil Promosi di PT. Sarana Pariwara Semarang Dengan Menggunakan Metode Exponential Smoothing Berbentu Program Minitab. Matematika: UNNES. 